\title{
Research
}

\section{Evaluating the Household Level Outcomes of Community Based Natural Resource Management: the Tchuma Tchato Project and Kwandu Conservancy}

\author{
Helen Suich $^{1,2}$
}

\begin{abstract}
Community based natural resource management (CBNRM) programs aim to link the achievement of conservation objectives with those of rural development and poverty alleviation. However, after more than a decade of implementation in southern Africa, there is remarkably little rigorous analysis of their achievements with respect to these goals. An evaluation of two CBNRM interventions, the Tchuma Tchato Project in Mozambique and the Kwandu Conservancy in Namibia, measured the impacts at the household level using multidimensional poverty indices. The analysis found no positive impacts on the multiple dimensions of poverty arising from the Tchuma Tchato initiative in Mozambique. In Kwandu Conservancy in Namibia, positive impacts were felt only on household financial capital on a disappointingly narrow scale. These results have important implications for policy makers and program designers and demonstrate the necessity of developing targeted strategies if poverty alleviation outcomes are to be achieved. Further, if the assumption that the provision of incentives is key to encouraging and maintaining participation in CBNRM is correct, the delivery of appropriate benefits that have a sufficient impact at the household level will be crucial for the long run sustainability of these initiatives.
\end{abstract}

Key Words: Africa; community based natural resource management; impact evaluation; Mozambique; Namibia; poverty

\section{INTRODUCTION}

Community based natural resource management (CBNRM) developed in southern Africa in response to a variety of environmental, social, and political pressures including the continued presence of biodiversity, particularly wildlife, on communal lands, and in response to political pressure to extend rights given to mainly white landowners to manage and benefit from wildlife on communal lands (Jones 1999, as cited in Fabricius et al. 2001, Jones and Murphree 2004). The need to stimulate rural development was also a driving force (Kiss 1990, Western et al. 1994, Blaikie 2006, Roe et al. 2009) because activities were frequently located in areas with high levels of poverty and few economic opportunities. Indeed, CBNRM has been "increasingly adopted as means of poverty reduction in the national development strategies of southern African countries" (Jones 2004:1).

To achieve their objectives, CBNRM programs aim to devolve rights over the management of certain natural resources to local communities, entitling these communities to a claim over the benefits generated from resource utilization (Bromley 1989). The provision of these incentives is assumed to change resource-use patterns, encourage their sustainable use (Murphree 1993, Bond 2001, Emerton 2001) and therefore achieve the continued survival of these resources on communal lands.

Wildlife resources on communal lands are the focus of CBNRM activities in much of southern Africa, and photographic and hunting tourism are the most important means of generating benefits from these resources. These benefits can be both financial, e.g., tourism revenues and wages/salaries, and nonfinancial, e.g., skills and experience from employment, increased access to and returns from physical assets, and increased social cohesion. When such benefits from CBNRM activities are delivered to residents within these communities, then rural development and poverty alleviation objectives can be achieved.

Concerns about how adverse results of impact evaluations may undermine support for initiatives (Pritchett 2002, Bourguignon and Pereira da Silva 2003, Cohen and Easterly 2009) mean that evaluations have been infrequently undertaken, and CBNRM initiatives are not unusual in this respect. There has been little systematic monitoring and evaluation of CBNRM initiatives, other than those required by donors (Barrett et al. 2001, Ferraro 2009), which typically examine only those aspects of a program funded by an individual donor, do not consider the program holistically, and often focus on the process of project or activity implementation rather than program outcomes and impacts.

With respect to the outcomes of CBNRM in southern Africa, the literature suggests that although positive environmental outcomes have been observed, they have rarely been quantified because of the lack of systematically collected and analyzed wildlife monitoring data (Newmark and Hough 2000, Arntzen 2006). The conservation outcomes of most southern African CBNRM programs are therefore uncertain, though in some cases increases in wildlife numbers are apparent (Taylor 2009, NACSO 2011). Further, despite the frequent adoption of CBNRM into policy and legal reforms, 
institutional and political constraints have meant that local level decision making powers have often been only incompletely devolved (Murphree 2004, Nelson and Agrawal 2008).

Some CBNRM programs have documented the estimated economic impacts, or total value of benefits generated (Emerton 2001, Taylor 2009, NACSO 2011), and detailed descriptions do exist regarding the wide range of impacts on livelihoods from CBNRM activities (Hulme and Murphree 2001, Fabricius and Koch 2004; Table 1).

However, the data that are frequently used to describe and demonstrate the benefits generated, e.g., the number of residents living in and hectares of land covered by community conservation areas, total revenues generated, and proportions of revenue generated by different activities are inappropriate as measures of impact at the household level. These data are highly aggregated and provide no evidence of the level of impact at the individual or household level, of the distribution of costs and benefits among residents, or of the proportion of residents affected. Even after more than a decade of CBNRM activities at many sites, virtually no research has been conducted that attempts to quantify the actual extent or importance of these impacts at the individual or household level. This is a significant oversight.

Such evaluations are critical to understanding whether and how an intervention meets its objectives and how these evaluations can contribute to improving the design and future outcomes of programs. They can also provide important information for decision making about how to allocate resources most effectively (Sanderson 2002). Through evaluation, we propose to address some of the knowledge gaps relating to the size and extent of impacts at the household level arising from CBNRM activities.

\section{METHODS}

\section{Study sites}

Two sites with CBNRM activities were evaluated: the Tchuma Tchato project in Tete Province, Mozambique and the Kwandu Conservancy in the Caprivi Region of Namibia, in which CBNRM activities were initiated in 1994/95 and 1996, respectively.

Because of the long and uncertain time lags between the implementation of activities and their effects, the choice of these sites for evaluation was made partially on the basis of the length of time CBNRM activities had been implemented. Sites were also selected on the basis that they were, or had once been, considered successful in some element of implementation by scholars and practitioners. It was assumed that successful initiatives would be the most likely to generate the largest and the widest range of positive impacts. Consideration was also given to the similarity of sites, in terms of human and wildlife population densities in particular, to many other CBNRM initiatives in the region to maximize the potential relevance of these results across the widest possible area.

\section{The Tchuma Tchato Project, Mozambique}

The Tchuma Tchato Project was the first CBNRM project implemented in Mozambique. It started in the Bawa community, in Tete Province in the northwest of the country, with the objective of improving the poor relationship between the local community and a trophy-hunting concessionaire. The project aimed to establish greater local control over resources and the resource-exploiting activities of outsiders and to obtain benefits from the utilization of these resources.

A central government decree allowed tax revenues generated from safari hunting operations in the Tchuma Tchato Project area to be split between local communities and local and central governments. To maximize revenues for the project, the central government also set especially high trophy prices for the Tchuma Tchato area. Project activities were expanded to the Daque area, the focus of our research, at the request of the local community following revenue distributions in Bawa. The Daque area is in the Magoé District, also in Tete, on the southern shore of Lake Cahora Bassa.

Although the sharing of revenues with local communities was assumed to encourage collaboration in resource management, poverty alleviation objectives became more explicit as the project evolved. These objectives related to the equity of partnerships that local communities were involved in, their ability to participate effectively in resource management activities and decision making, and most specifically, the generation and equitable distribution of benefits from wildlife management for poverty alleviation (Filimão et al. 1999).

In practice, project activities in the Daque area have focused on wildlife management. Few community or economic development activities have been initiated, although the project facilitated the establishment of elected village councils to undertake financial and environmental management decisions in collaboration with game scouts and other project staff.

Village committees used community revenues to purchase maize grinding mills, livestock, and a cart and irrigation foot pump, as well as to invest in small local businesses and to build a market building. Cash has been distributed twice, but this is no longer done because government feels that community benefits are more effective than cash payouts to individuals (Suich 2013).

Financial and technical assistance for the project were provided by the Ford Foundation, the International Development Research Centre, International Union for the Conservation of Nature Mozambique, and the Centre for Applied Social Sciences at the University of Zimbabwe. 
Table 1. Potential impacts on multiple dimensions of poverty arising from community based natural resource management activities. Source: adapted from Suich (2010a).

\begin{tabular}{ll}
\hline \hline Dimension & Impact \\
\hline Financial & Increased income and income security - from full-time, part-time, or casual employment from natural \\
& resource harvesting and/or production activities, from distribution of conservancy income (e.g., benefit \\
distributions). & Reduced income - from human-wildlife conflict reducing surplus agricultural production. \\
& Increase in skills and experience - from employment. \\
Human & Increased promotion and/or employment opportunities - from employment and training. \\
& Increased access to (legal) game meat - meat distributions from trophy and community hunting. \\
& Increased food availability - game meat distributions. \\
& Reduced household food availability - from human-wildlife conflict. \\
& Reduced access to (illegal) game meat - improved wildlife monitoring and reduced poaching. \\
& Improved harvests and thus food security - from conservation farming activities. \\
& Improved integration of natural resource management. \\
& Reduced access to land and/or resources resulting from zoning/allocating land for wildlife and/or \\
Natural & tourism. \\
& Improved access to, or returns from, physical assets (e.g., infrastructure) - from the investment of \\
Physical & community/conservancy income. \\
& Reduced access to, or returns from, physical infrastructure - from wildlife damage. \\
& Greater social cohesion and empowerment - participation in decision making, relationships with other \\
Social & local institutions, ability to meet own needs, ability to resolve conflict. \\
& Exacerbation and/or creation of conflicts - resulting from conservancy formation and/or benefit \\
distribution and/or exclusion from decision making and/or management style.
\end{tabular}

Provincial and central governments also played key roles in creating enabling conditions and in project implementation. Project activities have continued since the withdrawal of external support in the early 2000s, though budget constraints have negatively affected all project activities.

\section{Kwandu Conservancy, Namibia}

The Kwandu Conservancy, in the Caprivi Region, is one of more than 50 community conservation areas established within the Namibian national CBNRM program, the early activities of which started in the late 1980s. Though Kwandu was not formally recognized by the government until 1999, CBNRM activities have been taking place since 1996.

The national program is increasingly integrated in rural development and poverty alleviation planning (Jones 2004), and the conservancy has specific objectives related to impacts on members: "to conserve natural resources for wildlife for future generations, to benefit the members of Kwandu Conservancy in a fair way so that their quality of life is increased" (Kwandu Conservancy, personal communication). More specifically, it aims to "alleviate poverty and give employment to people by conserving wildlife ... [and] through benefit sharing from tourism revenues" (C. Muyoba, Manager Kwandu Conservancy, personal communication).

The conservancy undertakes a range of activities that are managed and implemented day-to-day by the conservancy staff and the overseen by the conservancy committee. Activities focus on wildlife management, including a number that deal specifically with human-wildlife conflict, such as chilli growing and the Human Animal Conflict Compensation Scheme (HACCSIS). The latter awards monies to members, under strictly defined conditions, for the loss of livestock, human injury, and crop damage. Such targeted activities are necessary because of the very high levels of human-wildlife conflict experienced in the conservancy, which are among the highest in Namibia (NACSO 2005). Other conservancy activities include fire management and the promotion of both conservation agriculture and of craft production and their sales, the latter undertaken primarily by women. The conservancy generates income from trophy hunting activities and a community campsite operating in the neighboring national park. Several small, formal benefit distributions have occurred; tree seedlings were distributed in 2005 and 2006, and cash totalling approximately \$US10,000 was distributed in 2003, 2004, and 2007.

Kwandu Conservancy has received financial and technical support from the nongovernment organization Integrated Rural Development and Nature Conservation, the Namibian Association of CBNRM Support Organizations, the Namibia Nature Foundation, and the Ministry of Environment and Tourism, though it is now financially self-supporting.

\section{Research design}

Multidimensional poverty

A wide range of impacts, both positive and negative, arising from CBNRM activities has been described (Table 1). To 
increase the probability of capturing the widest possible range of financial and nonfinancial impacts, household-level impacts were measured using a multidimensional poverty framework. This choice, to measure impacts on the multiple dimensions of poverty, was also based on the recognition that poverty occurs within, and is affected by, the political, economic, social, and cultural context (Narayan et al. 2000, Harriss 2009) enabling a better understanding of poverty and the interactions between different dimensions than would be possible with the more frequently used single, economic measure of income poverty.

Financial, human, natural, physical, and social dimensions of poverty were measured, following the use of the sustainable livelihoods framework in poverty analyses (Norton and Foster 2001, Moser and Felton 2007). However, the validity of questions about the quantitative measurement of multidimensional poverty, including which dimensions should be measured (Alkire 2007) and the accuracy of measurement of sometimes vague concepts (Qizilbash 2003), is recognized. These issues were dealt with by precisely defining indicators to be measured and selecting a comprehensive range of indicators from both a review of the most commonly used measures of poverty (Suich 2010b) and impacts described in the literature that arise from specific CBNRM activities, even if these activities were not known to have occurred in the study areas.

The financial dimension measures the financial resources available, e.g., savings, supplies of credit, remittances and pensions, consumption, and productive assets, to provide people with different livelihood options. The human dimension refers to the skills, knowledge, ability to labor, and good health important to the ability to pursue different livelihood strategies, including investments in education, health, nutrition, etc., that enable individuals to earn returns from their labor. The natural dimension refers to the natural resource flows that underpin livelihoods, e.g., land, water, wildlife, and wider environmental resources. The physical dimension measures the basic infrastructure, i.e., transport, shelter, water, energy, and communications that enable people to pursue livelihoods. And finally, the social dimension is defined as the social resources, i.e., networks, membership of groups, relationships of trust, and access to wider institutions of society, upon which people draw in pursuit of livelihoods.

In addition to quantitative objective metrics, subjective metrics to represent the psychological elements and perceptions of poverty were also used because they have been identified as an important element of multidimensional poverty and are a useful complement to objective assessments (Frey and Stutzer 2002, Anand and Clark 2006). Each indicator was therefore measured both objectively and subjectively. The subjective data collected related to 2 time periods, the time of the survey and 10 years earlier, to deal with the lack of baseline socioeconomic data at both sites (Kingdon and Knight 2004, Addison et al. 2008, Bamberger 2009) and to determine whether there were attitudinal differences in the subjective measures of 2 the groups. To minimize recall bias and associated issues by asking about absolute levels or quantities for these indicators, respondents were asked whether the household status 10 years earlier with respect to each indicator was worse than, better than, or the same as it was at the time of the survey. This enabled the analysis of the direction of change in the perceived status of different dimensions of household poverty over time.

Qualitative data relating to the multidimensional poverty status of households were collected in the household survey, during focus group discussions held in each village visited, and in key informant interviews. The results of the quantitative data analysis supplemented with results of the qualitative analyses where appropriate were correct at the time of the fieldwork, late 2007, but may have since changed given that specific project activities change and evolve over time, and the CBNRM initiatives are implemented in dynamic situations.

\section{Quasi-experimental design}

The purpose of this analysis was to identify positive or negative effects, whether intended or not, on the various dimensions of household poverty resulting from CBNRM activities. Establishing what would have occurred in the absence of the intervention, i.e., the counterfactual, is the fundamental problem of evaluation because it cannot be directly observed. It must be credibly estimated, and plausible alternative interpretations of outcomes have to be ruled out (Shadish et al. 2002, Ferraro 2009). Quasi-experimental methods rely on the use of statistical techniques to construct the counterfactual (Ravallion 2007).

Two samples were selected for comparison to help construct the counterfactual. The first sample, known as the 'CBNRM area' group, comprised households that lived within the CBNRM area, be that the Kwandu Conservancy or Tchuma Tchato. In Mozambique, five of the six villages in the Daque area involved in the Tchuma Tchato Project were visited. In Namibia, 4 out of 15 villages within the Kwandu Conservancy were visited. These villages were selected to represent the range of conditions within the conservancy, in terms of size, remoteness, access to services, and proximity to the conservancy office, to test whether these factors had an impact on household-level poverty. The second sample, known as the 'comparison' group, comprised households that lived outside the CBNRM areas and who, therefore, had not been affected by CBNRM activities. In both countries, comparison villages were selected to be as similar in every way and as geographically close to the CBNRM area villages as possible, but outside the influence of CBNRM activities. Each comparison village was selected on the basis of its similarity 
with respect to resource base, size, ethnicity, geography/ ecology and physical infrastructure, and particularly activities undertaken to sustain livelihoods, to reduce selection bias of the households sampled within these sites. In each country, three comparison villages were visited.

Two sampling strategies were used to select the households to be surveyed (Table 2). Random sampling was used to select households in the comparison group and to select a group of households within Kwandu Conservancy and the Tchuma Tchato Project area. The second strategy involved the selection of a purposive sample within the CBNRM area, which comprised households chosen specifically because one or more household members were, or had once been, involved in implementing CBNRM activities and/or were known to have been in direct receipt of benefits from those activities. The rationale for this was to investigate distributional issues surrounding the costs and benefits of CBNRM, in particular, to investigate whether benefits were seized by the group closely involved in program activities or were equitably spread among residents.

Table 2. Household survey sample size by category. CBNRM $=$ community based natural resource management.

\begin{tabular}{lcc}
\hline \hline & $\begin{array}{c}\text { Tchuma } \\
\text { Tchato }\end{array}$ & $\begin{array}{c}\text { Kwandu } \\
\text { Conservancy }\end{array}$ \\
\hline Purposive & 50 & 46 \\
Random (inside CBNRM area) & 69 & 68 \\
Comparison area & 68 & 72 \\
Total & 187 & 185 \\
Total population & $\mathrm{n} / \mathrm{a}$ & 4300 \\
\hline
\end{tabular}

\section{Data analysis}

Multivariate statistical techniques, i.e., factor analysis (FA) and principal component analysis (PCA), were used to reduce the dimensionality and improve the handling of the data. Both FA (Paim 1995, Sahn and Stifel 2000, 2003, Petrovici and Gorton 2005) and PCA (Klasen 2000, Filmer and Pritchett 2001, Amarasinghe et al. 2005, Moser and Felton 2007, Fujii 2008) have been used in multidimensional poverty analyses. However, because it is uncommon to use these methods to determine whether differences exist between groups, as opposed to identifying and counting those falling under a poverty line, both FA and PCA were used to ensure the robustness of the results and as a check against their misinterpretation.

Indices were constructed for each of the five dimensions of poverty, for the objective and both subjective measurements. Given the large number of indicators, multiple indices were constructed rather than a single composite index because the latter would aggregate across all dimensions and result in a loss of information. The use of multiple indices also enabled a more detailed analysis of the range of impacts observed on each of the dimensions measured. The indices constructed are described in Table 3 for Tchuma Tchato and Table 4 for Kwandu Conservancy. These tables provide names and interpretations for each index constructed. Single factors were most commonly extracted, allowing a simple interpretation of the factor, e.g., Fin-O1 is the one objectively measured financial dimension. Indices were named according to the dimension they measure, e.g., Fin for financial, followed by a reference to the type of data, $\mathrm{O}$ refers to an objective measure, Sn to a subjective measure at the time of the survey, and Sh to a subjective measure 10 years prior. The number indicates how many indices within each dimension were extracted, for example, Phys-Sn2 is the second index measuring subjective current physical capital.

Every effort was made to use the same variables in the construction of the poverty indices using both FA and PCA for both the Tchuma Tchato and Kwandu data. Differences in the data, typically arising from a lack of variation within variables, means that some minor differences exist in the construction of the sets of indices for the two countries. The sample specificity of the weights generated by FA and PCA are recognized and caution should be exercised in extrapolating beyond the samples used in this research. Our results are derived from the FA analysis, supplemented by those of the PCA analysis only when they differ. Summary tables of all analyses are available on request from the author.

The mix of categorical and binary variables necessitated polychoric transformations (made in Stata 10.1; Kolenikov and Angeles 2009) to be made prior to the construction of the poverty indices. The interpretation of the factor scores calculated for the objectively measured data is therefore not straightforward. Because the purpose of this analysis is not to identify households above or below a poverty line, but to test for statistically significant differences, the results in the tables present the t-statistics to facilitate the identification of differences, or similarities, between the groups.

Propensity Score Matching (PSM) enables impact evaluations to be conducted where randomization has not been integrated into the design of the intervention, and in cases in which there is no baseline or preintervention data, by matching the CBNRM area and comparison groups based on the similarity of a number of observable characteristics. It also enables the subsequent use of estimation techniques to determine the differences between two groups by comparing differences in the observed mean outcome, i.e., each poverty index, of each group. Propensity Score Matching has the advantage that it does not require a parametric model and allows impact estimation without making assumptions about functional form or error distributions (Bourguignon and Pereira da Silva 2003, Jalan and Ravallion 2003, Ravallion 2003). 
Table 3. Tchuma Tchato: Factor analysis-constructed poverty indices named and described, and the impacts of project activities on these poverty dimensions (community based natural resource management [CBNRM] area and comparison group).

\begin{tabular}{|c|c|c|c|c|c|}
\hline Dimension & Dimension interpretation & $\begin{array}{c}\text { Average } \\
\text { treatment } \\
\text { effect on the } \\
\text { treated } \\
\text { (ATT) T- } \\
\text { statistic }\end{array}$ & $\begin{array}{c}\mathrm{n}= \\
\text { comparison }\end{array}$ & $\begin{array}{c}\mathrm{n}=\text { treated } \\
(\mathrm{CBNRM} \\
\text { area })\end{array}$ & $\begin{array}{l}\text { Revised T- } \\
\text { statistic }^{\dagger}\end{array}$ \\
\hline \multicolumn{6}{|l|}{ Objective } \\
\hline Fin-O1 & Financial capital & -0.51 & 61 & 98 & -0.51 \\
\hline Hum-O1 & Current household human capital & -1.49 & 62 & 104 & -1.48 \\
\hline Hum-O2 & Future household human capital & 0.82 & 62 & 104 & 1.70 \\
\hline Nat-O1 & Natural capital & -1.66 & 65 & 109 & -1.55 \\
\hline Phys-O1 & Productive physical assets & 0.28 & 65 & 106 & 0.00 \\
\hline Phys-O2 & Household physical assets & -0.82 & 65 & 106 & -1.00 \\
\hline Soc-O1 & Extent of social networks & $-2.96 * *$ & 56 & 99 & $-4.45 * * \ddagger$ \\
\hline Soc-O2 & Intensity of social networks (over time) & 0.41 & 56 & 99 & 0.55 \\
\hline \multicolumn{6}{|c|}{ Subjective (at time of survey) } \\
\hline Fin-Sn1 & Current financial capital & -0.31 & 47 & 71 & -0.32 \\
\hline Hum-Sn1 & Current human capital & $-2.65 * *$ & 52 & 87 & $-2.87 * *$ \\
\hline Nat-Sn1 & Current natural capital & 0.51 & 55 & 88 & 0.48 \\
\hline Phys-Sn1 & Current access to physical capital (excluding water) & $-2.88 * *$ & 37 & 76 & $-2.67 * *$ \\
\hline Phys-Sn2 & Current access to water & -0.59 & 37 & 76 & -0.48 \\
\hline Soc-Sn1 & Current social capital & -0.67 & 53 & 101 & -0.66 \\
\hline \multicolumn{6}{|c|}{ Subjective (10 years prior) } \\
\hline Fin-Sh1 & Financial capital 10 years ago & -0.53 & 46 & 75 & -0.48 \\
\hline Hum-Sh1 & Human capital 10 years ago & 0.03 & 52 & 79 & 0.03 \\
\hline Nat-Sh1 & Natural capital 10 years ago & 0.57 & 57 & 97 & 0.52 \\
\hline Phys-Sh1 & Physical capital 10 years ago & -1.16 & 39 & 73 & -0.76 \\
\hline Soc-Sh1 & Social capital 10 years ago & -0.04 & 59 & 98 & -0.02 \\
\hline
\end{tabular}

T-statistic revised on the basis of bootstrapped standard errors

* coefficient estimate is significantly different at the $95 \%$ confidence level

** coefficient estimates are significantly different at the $99 \%$ confidence level

* significant differences using the Bonferroni and Šidák adjustments

Propensity Score Matching was used to construct the counterfactual (Rosenbaum and Rubin 1983) and to reduce selection bias (Baser 2006, Ravallion 2007). Every effort was made to use the same models to estimate the propensity scores for both sites. Matching was conducted on common support and on the use of five nearest neighbor matchings, and PSM was carried out in Stata, using the 'psmatch2' command (Leuven and Sianesi 2003). Bootstrapped standard errors were estimated and revised t-statistics calculated to take into account the fact that the propensity score is estimated (Lechner 2002, Blundell et al. 2005). Both the original and revised tstatistics are reported to indicate the sensitivity of the data.

Given that multiple tests were performed, Bonferroni and Šidák adjustment procedures were conducted to account for Type I errors, i.e., rejecting the hypothesis when it is true, as approximately $5 \%$ could appear to be significant purely by chance (Abdi 2007). These corrections are shown in the tables and are the focus of the results.
Additional analyses were undertaken to determine the distribution of impacts within the CBNRM area. These analyses involved testing for differences between the purposive and random samples within each CBNRM area and also for differences between the two groups of randomly sampled households in each country. These were designed to determine whether or not the inclusion of the purposive households in the CBNRM area group masked differences between the two randomly sampled groups.

\section{RESULTS}

\section{The Tchuma Tchato Project, Mozambique}

Although national human development and human poverty indicators improved over the period under consideration (UNDP 2000, 2006), the level and depth of poverty do not appear to have changed significantly in the villages visited, though inequality may have increased somewhat. According to focus groups, households were particularly vulnerable to 
Table 4. Kwandu Conservancy: Factor analysis-constructed poverty indices named and described, and the impacts of activities on these poverty dimensions (community based natural resource management [CBNRM] area and comparison group).

\begin{tabular}{|c|c|c|c|c|c|}
\hline Dimension name & Dimension interpretation & $\begin{array}{c}\text { Average } \\
\text { treatment } \\
\text { effect on the } \\
\text { treated (ATT) } \\
\text { T-statistic }\end{array}$ & $\begin{array}{c}\mathrm{n}= \\
\text { comparison }\end{array}$ & $\begin{array}{c}\mathrm{n}= \\
\text { treated } \\
(\mathrm{CBNRM} \\
\text { area) }\end{array}$ & $\begin{array}{c}\text { Revised T- } \\
\text { statistic }^{\dagger}\end{array}$ \\
\hline \multicolumn{6}{|l|}{ Objective } \\
\hline Fin-O1 & Financial capital & 1.08 & 64 & 98 & 0.98 \\
\hline Hum-O1 & Health and food security & -1.66 & 64 & 103 & -1.36 \\
\hline Hum-O2 & Gender, sufficient and adequate clothing & -0.61 & 64 & 103 & -0.76 \\
\hline Nat-O1 & Plant and other natural resource use & -0.18 & 64 & 104 & -0.23 \\
\hline Nat-O2 & Livestock production & -0.76 & 64 & 104 & -0.67 \\
\hline Phys-O1 & Consumption infrastructure & $-2.10 *$ & 60 & 104 & $-2.30 *$ \\
\hline Phys-O2 & Productive infrastructure & 1.64 & 60 & 104 & 1.91 \\
\hline Soc-O1 & Social capital & 1.04 & 59 & 88 & 0.87 \\
\hline \multicolumn{6}{|c|}{ Subjective (at time of survey) } \\
\hline Fin-Sn1 & Current financial capital & -0.39 & 59 & 91 & -0.38 \\
\hline Hum-Sn1 & Current human capital & 0.48 & 62 & 100 & 0.42 \\
\hline Nat-Sn1 & Current national capital & 0.51 & 59 & 85 & 0.50 \\
\hline Phys-Sn1 & Current physical capital & -0.10 & 54 & 90 & -0.09 \\
\hline Soc-Sn1 & Current social capital & 0.14 & 61 & 100 & 0.13 \\
\hline \multicolumn{6}{|c|}{ Subjective (10 years prior) } \\
\hline Fin-Sh1 & Income 10 years ago & 1.26 & 56 & 92 & 0.86 \\
\hline Fin-Sh2 & Household credit and debt position 10 years ago & 1.13 & 56 & 92 & 1.28 \\
\hline Hum-Sh1 & Human capital 10 years ago & -1.69 & 62 & 96 & -1.65 \\
\hline Nat-Sh1 & Natural capital 10 years ago & 0.07 & 57 & 83 & 0.06 \\
\hline Phys-Sh1 & Physical capital 10 years ago & -1.12 & 51 & 91 & -1.02 \\
\hline Soc-Sh1 & Social capital 10 years ago & -1.84 & 61 & 98 & -1.90 \\
\hline
\end{tabular}

${ }^{\dagger}$ revised on the basis of the bootstrapped standard error

* coefficient estimate is significantly different from zero at $95 \%$ confidence level

adverse climatic conditions and other factors affecting agricultural productivity and livestock health. Human-wildlife conflict was also of concern to households, and wildlife numbers were reported by villagers to have increased over the 10-year period.

The results of the PSM, using the poverty indices constructed using FA, are that the only statistically significant difference, following the Bonferroni and Šidák adjustments, was for the objectively measured social dimension (Table 3). Analysis of the indicators revealed that significantly fewer CBNRM area households believed there was trust in their village, and that they could obtain help from fellow villagers in times of crisis. It is unclear why differences existed between the two groups, but they run counter to the argument that CBNRM activities contribute to increased social capital (Lise 2000, Bar-On 2005, Walpole and Wilder 2008).

The Type I error-adjusted results for the PCA constructed indices indicate that differences existed within the subjectively measured current human dimension. Tchuma Tchato households were more positive than comparison households about the characteristics of their human capital. However, because Tchuma Tchato has not invested in the provision of goods or services to strengthen human capital, these differences, although statistically significant, are not thought to be attributable to project activities.

These important results indicate that few significant differences can be found between the CBNRM area and comparison groups and imply that no discernible positive impact on the multiple dimensions of poverty can be attributed to the Tchuma Tchato Project. The results of the analysis comparing the two groups of randomly selected households confirmed those in Table 3, strengthening the conclusions about the Tchuma Tchato Project's lack of impact on poverty.

An important caveat must be made to this statement. Because of the lack of baseline data, it is not possible to say with absolute certainty that the status of households in the CBNRM area and comparison groups, relative to each other, has not changed over time. However, the absence of differences between the two groups with respect to perceptions of 
Table 5. Tchuma Tchato: impact of project activities on poverty dimensions, purposive and random group (within community based natural resource management [CBNRM] area).

\begin{tabular}{|c|c|c|c|c|}
\hline \multirow[t]{2}{*}{ Dimensions } & \multicolumn{4}{|c|}{ Factor analysis-constructed indices } \\
\hline & $\begin{array}{l}\text { Average treatment } \\
\text { effect on the } \\
\text { treated (ATT) T- } \\
\text { statistic } \\
\end{array}$ & $\begin{array}{c}\mathrm{n}=\text { random }(\mathrm{CBNRM} \\
\text { area })\end{array}$ & $\mathrm{n}=$ purposive & Revised T-statistic ${ }^{\dagger}$ \\
\hline \multicolumn{5}{|l|}{ Objective } \\
\hline Fin-O1 & 1.84 & 58 & 40 & 1.72 \\
\hline Hum-O1 & -1.78 & 59 & 45 & -1.21 \\
\hline Hum-O2 & 1.23 & 59 & 45 & 1.30 \\
\hline Nat-O1 & $-2.19 *$ & 62 & 47 & -1.92 \\
\hline Phys-O1 & 1.39 & 60 & 46 & 0.96 \\
\hline Phys-O2 & -0.16 & 60 & 46 & -0.13 \\
\hline Soc-O1 & $-2.79 * *$ & 55 & 44 & $-2.08 *$ \\
\hline Soc-O2 & $3.29 * * \frac{1}{5}$ & 55 & 44 & $3.02 * * *$ \\
\hline \multicolumn{5}{|c|}{ Subjective (at time of survey) } \\
\hline Fin-Sn1 & -0.14 & 40 & 31 & -0.10 \\
\hline Hum-Sn1 & -0.19 & 47 & 40 & -0.13 \\
\hline Nat-Sn1 & -1.77 & 53 & 35 & -1.58 \\
\hline Phys-Sn1 & -1.23 & 43 & 33 & -0.66 \\
\hline Phys-Sn2 & $-2.34 *$ & 43 & 33 & -1.48 \\
\hline Soc-Sn1 & -1.26 & 59 & 42 & -1.23 \\
\hline \multicolumn{5}{|l|}{ Subjective (10 years prior) } \\
\hline Fin-Sh1 & $-2.11^{*}$ & 39 & 36 & -1.52 \\
\hline Hum-Sh1 & -1.20 & 43 & 36 & -0.89 \\
\hline Nat-Sh1 & $-2.56^{*}$ & 56 & 41 & -1.87 \\
\hline Phys-Sh1 & -1.63 & 44 & 29 & -1.31 \\
\hline Soc-Sh1 & -0.91 & 56 & 42 & -0.79 \\
\hline
\end{tabular}

\footnotetext{
${ }^{\dagger}$ T-statistic revised on the basis of bootstrapped standard errors

* coefficient estimate is significantly different from zero at $95 \%$ confidence level

** coefficient estimate is significantly different from zero at $99 \%$ confidence level

* significant differences using the Bonferroni and Šidák adjustments
}

household status either at the time of the survey or 10 years prior suggests that it is unlikely that the relative status of households has changed over time. This caveat is equally relevant to the results of the Kwandu Conservancy evaluation.

The results of the comparison of the two groups within the Tchuma Tchato project area are presented in Table 5. The Bonferroni and Šidák adjustments indicate a statistically significant difference between the two groups for the objectively measured social dimension. The PSM conducted on the PCA-constructed poverty indices also indicated significant differences in the objectively measured physical dimension.

Further analysis of the social dimension indicated that purposive households had fewer sources of help in the face of severe household stress than random households. Although purposive households reportedly worked together within the village more frequently than random households, they were more likely to think that trust levels within the village had changed in the last decade and to think that levels of trust in their village were worse than in other villages.

In recent years, the Tchuma Tchato employment policy changed from preferentially hiring local employees, to decisions based solely on the merit of applicants, regardless of their origin (Luis Namanha, Director, Direcçao Provincial do Turismo, Tete, personal communication). It is possible that the 'outsider' status of recent Tchuma Tchato employees had a negative impact on their social capital. Further research would be necessary to determine whether this is true. The apparent differences in the physical dimension are thought to be unrelated to Tchuma Tchato activities because the project made no investment in the provision of physical capital. In summary, these results indicate that the Tchuma Tchato Project had no significantly positive impact on the five measured dimensions of household poverty. 


\section{Kwandu Conservancy, Namibia}

In the period under consideration, Namibian economic growth rates have not been fast enough to significantly reduce high levels of poverty and inequality. National human development appears to be in long-term decline, with life expectancy declining, largely attributable to HIV/AIDS, more quickly than increases in household income and educational attainment (Levine 2007). These trends hold true for the villages visited, with focus groups reporting that local poverty levels were increasing because of HIV/AIDS, the effects of inflation, and a reduction in formal employment opportunities. Focus groups also identified household-level vulnerability to the death and/or illness of household members, primarily because of HIV/AIDS, to extreme climatic conditions and other factors affecting agricultural productivity, particularly human-wildlife conflict.

The results of the analysis involving the Namibian CBNRM area and comparison groups show no significant differences following the Bonferroni and Šidák adjustments (Table 4). This indicates that there is no statistically observed treatment effect, i.e., no observable impact, arising from the activities of the Kwandu Conservancy on the households living within the conservancy. The comparison between the random and comparison groups mirrored these results and does not change the overall conclusion that no differences can be observed between the CBNRM area and comparison group households.

In the comparison between the two groups within the Kwandu Conservancy (Table 6), only the objectively measured financial dimension was statistically significantly different following the Bonferroni and Šidák adjustments. The results of the PSM tests for the PCA-constructed poverty indices also indicated a difference between the two groups for the objectively measured physical dimension of poverty.

Further analysis of the financial dimension indicated that the purposive group was richer, i.e., households were in higher income quintiles and more likely to own a greater number and a wider range of asset types, than households in the random group. Differences in the objectively measured physical dimension indicated that random households had better access to physical capital than purposive households, though the conservancy did not undertake any investments that would have improved households' access to physical capital. These differences are thought to be unrelated to CBNRM activities, but rather reflect improvements in physical capital undertaken largely by government, including water sources, all-weather roads, and access to agricultural markets, unevenly across the Caprivi region.

The higher status with respect to financial poverty of the purposive group is perhaps unsurprising given that the heads of 24 of the 46 households in the sample (52\%) were employed by the conservancy or in other formal employment. In the random sample, the heads of just two households (3\%) were formally employed and none were employed by the conservancy. This advantage in the financial dimension may also be partially attributable to the lower proportion of femaleheaded households than in the random group. Focus groups identified female-headed households as one characteristic of poor households.

In summary, positive impacts arising from CBNRM activities were felt by purposive but not random households within the CBNRM area. Given that purposive households were selected because they had been more closely involved in the management and benefit streams associated with the conservancy, and that many household members within this group were employed by the conservancy or otherwise formally employed, this result is perhaps not surprising.

\section{DISCUSSION}

\section{The Tchuma Tchato Project, Mozambique}

The evaluation of the Tchuma Tchato Project in Mozambique indicates that at the time of the fieldwork, the project had no discernible positive impacts on the multiple dimensions of poverty among households living in the project area. This lack of impact can be understood in the context of the relatively low level of benefits returned to these communities. Focus groups revealed that some form of benefit had been distributed to each village over the life of the project, and that the majority of benefits distributed were community rather than individual benefits. Although revenues had been used to purchase a range of assets (see description above and Suich 2013 for more detail), these benefits were largely dysfunctional at the time of the fieldwork and were thus no longer able to have a positive impact on households.

This lack of positive impact has significance for future levels of resident interest and participation in project activities and indicates that the project will have to radically alter its activities and level of benefits distributed at the household level if it is to have a positive impact on household poverty in the future. In his review of Bawa community participation in Tchuma Tchato, Johnson (2004) also noted the need to be cautious because of the potential for internal divisions that can arise from raising false expectations about the level of benefits that can be delivered by CBNRM activities.

\section{Kwandu Conservancy, Namibia}

In the evaluation of impacts on poverty in the Kwandu Conservancy in Namibia, no significant differences between the CBNRM area and comparison groups were found. However, objectively measured financial capital was found to be significantly higher among purposive households compared to randomly selected households within the conservancy, indicating that the Kwandu Conservancy had a positive impact on purposive households at the time of the survey. 
Table 6. Kwandu Conservancy: impact of project activities on poverty dimensions, purposive and random group (within community based natural resource management [CBNRM] area).

\begin{tabular}{|c|c|c|c|c|}
\hline \multirow[t]{2}{*}{ Dimensions } & \multicolumn{4}{|c|}{ Factor analysis-constructed indices } \\
\hline & $\begin{array}{l}\text { Average treatment } \\
\text { effect on the } \\
\text { treated (ATT) T- } \\
\text { statistic } \\
\end{array}$ & $\begin{array}{c}\mathrm{n}=\operatorname{random}(\mathrm{CBNRM} \\
\text { area })\end{array}$ & $\mathrm{n}=$ purposive & Revised T-statistic $^{\dagger}$ \\
\hline \multicolumn{5}{|l|}{ Objective } \\
\hline Fin-O1 & $3.12 * * *$ & 60 & 38 & 1.69 \\
\hline Hum-O1 & -0.99 & 63 & 40 & -0.72 \\
\hline Hum-O2 & 0.60 & 63 & 40 & 0.55 \\
\hline Nat-O1 & 0.02 & 64 & 40 & 0.01 \\
\hline Nat-O2 & $2.42 *$ & 64 & 40 & 1.60 \\
\hline Phys-O1 & $2.06^{*}$ & 64 & 40 & $3.09 * *$ \\
\hline Phys-O2 & -0.52 & 64 & 40 & -0.65 \\
\hline Soc-O1 & -0.22 & 53 & 35 & -0.12 \\
\hline \multicolumn{5}{|l|}{ Subjective (at time of survey) } \\
\hline Fin-Sn1 & $-2.06^{*}$ & 54 & 37 & -1.30 \\
\hline Hum-Sn1 & $2.32 *$ & 61 & 39 & 1.80 \\
\hline Nat-Sn1 & -0.74 & 51 & 34 & -0.52 \\
\hline Phys-Sn1 & 0.52 & 56 & 34 & 0.43 \\
\hline Soc-Sn1 & -0.68 & 61 & 39 & -0.42 \\
\hline \multicolumn{5}{|l|}{ Subjective (10 years prior) } \\
\hline Fin-Sh1 & 0.10 & 57 & 35 & 0.08 \\
\hline Fin-Sh2 & 1.48 & 57 & 35 & 0.96 \\
\hline Hum-Sh1 & $2.38^{*}$ & 59 & 37 & 1.72 \\
\hline Nat-Sh1 & $2.31 *$ & 49 & 34 & 1.66 \\
\hline Phys-Sh1 & $2.59 * *$ & 57 & 34 & 1.36 \\
\hline Soc-Sh1 & $2.46^{*}$ & 61 & 37 & 1.67 \\
\hline
\end{tabular}

\footnotetext{
${ }^{\dagger}$ revised on the basis of the bootstrapped standard error

* coefficient estimate is significantly different from zero at $95 \%$ confidence level

** coefficient estimate is significantly different from zero at $99 \%$ confidence level

* significant differences using the Bonferroni and Šidák adjustments
}

The relatively high and regular wages associated with the formal employment of purposive households is responsible for the positive impact on these households: almost half of the purposive group were current or former employees of the conservancy, or were employed by tourism enterprises at the time of the fieldwork.

The lack of impact on the randomly selected households within Kwandu likely arises from the relatively low value of benefits distributed to these households. The conservancy had distributed game meat to households relatively frequently and had also distributed cash to the five area Khutas, i.e., seats of traditional government, several times. However, the amounts distributed have been relatively small, approximately \$US1500 to each of the five Khutas in 2003 and 2004, and \$US470 in 2007 (C. Muyoba, personal communication).

\section{Comparing Tchuma Tchato and Kwandu Conservancy}

With the wider range of activities undertaken in Kwandu Conservancy compared to Tchuma Tchato, a comparatively larger impact among random households was anticipated. It is thought that this larger impact did not occur because the bulk of self-reported benefits received at the individual level among random households in Kwandu Conservancy have, to date, been game meat distributions, which have had only fleeting impacts on households. Some activities that may be expected to exert a stronger influence on poverty, e.g., conservation agriculture and crop compensation under HACCSIS, may have been implemented too recently for any impact to have been detected.

Given the comparatively high employment levels within the purposive households of the Tchuma Tchato project, it is surprising that the positive impact on the financial dimension of the purposive group that occurred in Kwandu Conservancy did not also occur in Tchuma Tchato. This may be related to the low salaries paid and the sometimes infrequent nature of their payment, reducing certainty about household income and potentially having an impact on other dimensions of household poverty. It may also have been because the Mozambican 
purposive household sample had a smaller proportion of employees than did the Namibian purposive sample.

Although these positive impacts on purposive households in Kwandu Conservancy are impressive, they demonstrate a very narrow impact. The differences were driven by the employees of the conservancy and its enterprises, or those in other formal employment. Although these impacts are no doubt important to these households, they are estimated to directly affect fewer than $3 \%$ of households that reside in the conservancy.

Participation of communities is thought to be based on the expectation that the benefits, financial and otherwise, outweigh the costs of collective action and wildlife management (Jones 1999, Lubell 2002, Matta and Alavalapati 2006). The lack of discernible impact on any dimension of poverty in most households is therefore likely to be an important factor in householders' decisions about whether to continue to participate and whether their expectations have been met. If household-level impacts are indeed an important factor in decisions about continued participation, these results suggest the long-run sustainability of these initiatives may be in question if levels of positive impact are not increased to encourage participation.

Although disappointing, these results should also be considered in the context of local poverty dynamics. Despite rapid macroeconomic growth in Mozambique since the late 1990s, positive effects such as improved economic and employment opportunities arising from this growth have largely been absent in remote rural areas (Arndt et al. 2006), including those studied here. Qualitative data collected in the villages visited indicates that poverty and inequality have increased. In Namibia, over the same period, macroeconomic growth has been relatively slow and largely jobless (GRN 2008). Poverty levels in the villages visited are said by residents to have increased, particularly as a result of HIV/ AIDS. The epidemic has had significant negative impacts on both life expectancy and population growth rates (Mendelsohn et al. 2002, UNECA 2008).

The difficult economic climate increases the requirement for CBNRM activities to deliver positive impacts at the household level because they are not available elsewhere in the economy. Further, where poverty increases, it is likely that the reliance on natural resources will also increase, and the availability of subsistence resources is already reported by local communities to be declining in both countries. This will no doubt have a negative impact on wildlife if habitat is further degraded and wild food sources disappear, thereby compromising the conservation outcomes of these CBNRM initiatives and their ability to generate future benefits.

If poverty alleviation objectives are to be met in the future, CBNRM programs will need to generate more benefits from diverse sources. In particular, where human populations are high and growing, household-level impacts will necessarily be diluted unless benefits grow at the same rate, or faster, than populations (Barrett and Arcese 1998). Program designers and implementers will also need to consider more targeted poverty alleviation strategies, potentially including a choice between broad but shallow impacts and narrow but more significant impacts. Further research into the specific pathways by which CBNRM activities can have a positive impact on poverty at the household level is recommended, for example, by reducing exposure to, and improving management of, risk, particularly agricultural production risks, and contributing to householdlevel asset accumulation (Moser and Felton 2007).

Because this is the first analysis to measure impacts on multiple dimensions of poverty at the household level, there is no data from other CBNRM programs in the region with which to compare these results. However, it is plausible that these results hold true beyond the two sites considered, e.g., in areas with relatively high human population densities, relatively high levels of competition for tourism dollars, and/ or relatively limited tourism potential. In the absence of systematic monitoring of outcomes, it cannot be known if they hold for CBNRM programs implemented in different ecological, social, or economic conditions or in locations where revenues, generated and distributed, are significantly higher.

Despite the disappointing nature of these results, it is inappropriate to use them in advocating a 'back to the barriers' approach to conservation or preservationist ideology. This research investigated only one of the several objectives of CBNRM activities, and these results should not be considered in isolation from the achievements of other objectives. Other assessments of CBNRM programs across southern Africa report a number of benefits including, but not limited to, the devolution of property rights over wildlife to communities and changes in tenure over land, wildlife and/or other natural resources, increases in political voice, democratization and improved participation of previously marginalized groups, including women and youth (Hulme and Murphree 2001, Dalal-Clayton and Child 2003, Fabricius and Koch 2004, Long 2004, Roe et al. 2009, Suich et al. 2009). These benefits are difficult, if not impossible, to measure at the household level, and their omission from this analysis does not suggest that they are not present in Tchuma Tchato or Kwandu Conservancy.

With respect to the achievement of conservation objectives, qualitative evidence from focus group discussions suggests that both Tchuma Tchato and Kwandu Conservancy have been relatively successful in increasing local wildlife numbers and species diversity, indicating relatively greater success in achieving the sustainable utilization of wildlife species.

It is also possible that little or no wildlife would survive in these locations without these CBNRM activities. In the 
Caprivi Region, protected areas are too small to prevent wildlife from ranging outside of their borders (Tagg 1996), and in Tete Province there are no formal protected areas at all. Thus, although wildlife exists on communal lands, and questions remain about the effectiveness of protected areas, CBNRM and other community conservation initiatives should be viewed as complementing formal protected areas.

\section{CONCLUSION}

It can be concluded that the Tchuma Tchato Project in Mozambique has had little noticeable impact on the various dimensions of poverty measured at the household level. This lack of impact can be understood in the context of the relatively low level of benefits returned to these communities to date. These results suggest that the project will have to radically alter its activities and the level of benefits distributed at the household level if it is to have a positive impact on household poverty in the future.

After more than a decade of CBNRM activities in Kwandu Conservancy, its activities had almost no impact on the multiple dimensions of poverty for the majority of resident households. Positive impacts arising from conservancy activities were observable on purposive households, with these households having greater levels of financial capital. It is likely that this can be attributed, at least partially, to the direct benefits, particularly employment, arising from the conservancy. Although encouraging, these positive impacts were felt by very few conservancy residents.

To improve poverty impacts in the future, CBNRM programs will need to coordinate with other rural development and poverty alleviation strategies and increase the value of benefits generated. To date, CBNRM interventions to reduce poverty have relied on trickle-down effects, but these results demonstrate the necessity of developing targeted strategies to achieve poverty alleviation outcomes.

Despite the shortcomings in achieving poverty alleviation objectives, the spread and continued implementation of CBNRM activities suggest that CBNRM meets a need, even if it is not clear which need is met, or how. However, if the interest and participation of rural communities in CBNRM activities is to be maintained, and the sustainable utilization of resources is to be achieved, CBNRM programs must deliver improved poverty alleviation and benefit distribution outcomes in the future.

Responses to this article can be read online at: http://www.ecologyandsociety.org/issues/responses. php/5875

\section{Acknowledgments:}

Financial support was received from the Southern African Sustainable Use Specialist Group, World Conservation Union (IUCN) South Africa and the Crawford School of Public Policy, Australian National University. The opinions expressed in this paper are the author's own and do not necessarily represent the views of either of these organizations. All responsibility for any errors remains with the author. The anonymous reviewers are thanked for their useful comments and suggestions.

\section{LITERATURE CITED}

Abdi, H. 2007. Bonferroni test. Pages 103-106 in N. Salkind, editor. Encyclopaedia of measurement and statistics. Sage, Thousand Oaks, California, USA. [online] URL: http://www. utdallas.edu/ herve/Abdi-Bonferroni2007-pretty.pdf

Addison, T., D. Hulme, and R. Kanbur. 2008. Poverty dynamics: measurement and understanding from an interdisciplinary perspective. Brooks World Poverty Institute/ University of Manchester, Manchester, UK. http://dx.doi. org/10.2139/ssrn.1246882

Alkire, S. 2007. The missing dimensions of poverty data: introduction to the special issue. Oxford Development Studies 35:347-359. http://dx.doi.org/10.1080/13600810701701863

Amarasinghe, U., M. Samad, and M. Anputhas. 2005. Spatial clustering of rural poverty and food insecurity in Sri Lanka. Food Policy 30:493-509. http://dx.doi.org/10.1016/j.

foodpol.2005.09.006

Anand, P., and A. Clark. 2006. Symposium introduction: life satisfaction and welfare economics. Journal of SocioEconomics 35:177-179. http://dx.doi.org/10.1016/j.socec.2005.11.013

Arndt, C., S. Jones, and F. Tarp. 2006. Aid and development: the Mozambican case. Department of Economics, University of Copenhagen, Copenhagen, Denmark.

Arntzen, J. 2006. Case studies on successful southern African NRM initiatives and their impacts on poverty and governance. Country study: Botswana. Case study of the CBNRM programme in Botswana. International Union for Conservation of Nature Transboundary Protected Areas Research Initiative, IUCN, Gland, Switzerland.

Bamberger, M. 2009. Strengthening the evaluation of programme effectiveness through reconstructing baseline data. Journal of Development Effectiveness 1:37-59. http://dx. doi.org/10.1080/19439340902727610

Bar-On, A. 2005. On elephants, giraffes, and social development. Community Development Journal 41:367-380. http://dx.doi.org/10.1093/cdj/bsi069 
Barrett, C. B., and P. Arcese. 1998. Wildlife harvest in integrated conservation and development projects: linking harvest to household demand, agricultural production, and environmental shocks in the Serengeti. Land Economics 74:449-465. http://dx.doi.org/10.2307/3146878

Barrett, C. B., K. Brandon, C. Gibson, and H. Gjertsen. 2001. Conserving tropical biodiversity amid weak institutions. BioScience 51:497-502. http://dx.doi.org/10.1641/0006-3568 (2001)051[0497:CTBAWI]2.0.CO;2

Baser, O. 2006. Too much ado about propensity score models? Comparing methods of propensity score matching. Value in Health 9:377-385. http://dx.doi.org/10.1111/j.1524-4733.2006.00130. $\underline{\mathrm{x}}$

Blaikie, P. 2006. Is small really beautiful? Community-based natural resource management in Malawi and Botswana. World Development 34:1942-1957. http://dx.doi.org/10.1016/j. worlddev.2005.11.023

Blundell, R., L. Dearden, and B. Sianesi. 2005. Evaluating the effect of education on earnings: models, methods and results from the National Child Development Survey. Journal of the Royal Statistical Society. Series A 168:473-512. http://dx.doi. org/10.1111/j.1467-985X.2004.00360.x

Bond, I. 2001. CAMPFIRE and the incentives for institutional change. Pages 227-243 in D. Hulme and M. Murphree, editors. African wildlife and livelihoods: the promise and performance of community conservation. Heinemann, Oxford, UK.

Bourguignon, F., and L. Pereira da Silva. 2003. The impact of economic policies on poverty and income distribution. Evaluation techniques and tools. World Bank, Washington, D.C., USA.

Bromley, D. W. 1989. Property relations and economic development: the other land reform. World Development 17:867-877. http://dx.doi.org/10.1016/0305-750X(89)90008-9

Cohen, J., and W. Easterly, editors. 2009. What works in development? Thinking big and thinking small. Brookings Institute, Washington, D.C., USA.

Dalal-Clayton, B., and B. Child. 2003. Lessons from Luangwa: the story of the Luangwa Integrated Resource Development project, Zambia. International Institute for Environment and Development, London, UK.

Emerton, L. 2001. The nature of benefits and the benefits of nature. Why wildlife conservation has not economically benefited communities in Africa. Pages 208-226 in D. Hulme and M. Murphree, editors. African wildlife and livelihoods: the promise and performance of community conservation. Heinemann, Oxford, UK.
Fabricius, C., and E. Koch, editors. 2004. Rights, resources and rural development. Comunity-based natural resource management in southern Africa. Earthscan, London, UK.

Fabricius, C., E. Koch, and H. Magome. 2001. Towards strengthening collaborative ecosystem management: lessons from environmental conflict and political change in southern Africa. Journal of the Royal Society of New Zealand 31:831-844. http://dx.doi.org/10.1080/03014223.2001.9517679

Ferraro, P. J. 2009. Counterfactual thinking and impact evaluation in environmental policy. New Directions for Evaluation 2009:75-84. http://dx.doi.org/10.1002/ev.297

Filimão, E., E. Mansur, and L. Namanha. 1999. Tchuma Tchato: an evolving experience of community-based natural resource management in Mozambique. Pages 145-152 in Proceedings of the International Workshop on Community Forestry in Africa. Participatory forest management: a strategy for sustainable forest management in Africa. Food and Agriculture Organization of the United Nations, Forestry, Rome, Italy. [online] URL: ftp://ftp.fao.org/docrep/fao/006/ x7760b/X7760B19.pdf

Filmer, D., and L. H. Pritchett. 2001. Estimating wealth effects without expenditure data-or tears: an application to educational enrollments in states of India. Demography $38: 115-132$.

Frey, B. S., and A. Stutzer. 2002. What can economists learn from happiness research? Journal of Economic Literature 40:402-435. http://dx.doi.org/10.1257/002205102320161320

Fujii, T. 2008. How well can we target aid with rapidly collected data? Empirical results for poverty mapping from Cambodia. World Development 36:1830-1842. http://dx.doi. org/10.1016/j.worlddev.2007.10.013

Government of the Republic of Namibia (GRN). 2008. Third national development plan (NDP3) 2007/2008-2011/12 volume I executive summary. Government of the Republic of Namibia, Windhoek, Namibia. [online] URL: http://www. npc.gov.na/docs/NDP3 Executive_Summary.pdf

Harriss, J. 2009. Bringing politics back into poverty analysis. Why understanding of social relations matters more for policy on chronic poverty than measurement. Pages 205-224 in T. Addison, D. Hulme, and R. Kanbur, editors. Poverty dynamics. Interdisciplinary perspectives. Oxford University Press, Oxford, UK. http://dx.doi.org/10.1093/acprof: oso/9780199557547.003.0009

Hulme, D., and M. Murphree. 2001. African wildlife and livelihoods: the promise and performance of community conservation. James Currey, London, UK. 
Jalan, J., and M. Ravallion. 2003. Estimating the benefit incidence of an antipoverty programme by propensity score matching. Journal of Business and Economic Statistics 21:19-30. http://dx.doi.org/10.1198/073500102288618720

Johnson, S. 2004. The Tchumo Tchato project in Mozambique: community-based natural resource management in transition. Pages 210-222 in C. Fabricius, E. Koch, S. Turner, and H. Magome, editors. Rights, resources and rural development: community based natural resource management in southern Africa. Earthscan, London, UK.

Jones, B. T. B. 1999. Policy lessons from the evolution of a community-based approach to wildlife management, Kunene Region, Namibia. Journal of International Development 11:295-304. http://dx.doi.org/10.1002/(SICI)1099-1328(199903/04) 11:2<295::AID-JID583>3.0.CO;2-U

Jones, B. T. B. 2004. CBNRM, poverty reduction and sustainable livelihoods: developing criteria for evaluating the contribution of CBNRM to poverty reduction and alleviation in southern Africa. Institute for Poverty, Land and Agrarian Studies (PLAAS), Cape Town, South Africa. [online] URL: http://dspace.cigilibrary.org/jspui/bitstream/123456789/33686/1/ CBNRM\%2007.pdf?1

Jones, B. T. B., and M. W. Murphree. 2004. Community-based natural resource management as a conservation mechanism: lessons and directions. Pagesin B. Child, editor. Parks in transition: biodiversity, rural development and the bottom line. Earthscan, London, UK.

Kingdon, G. G., and J. Knight. 2004. Well-being poverty versus income poverty and capabilities poverty? Global Poverty Research Group, Centre for the Study of African Economies, Department of Economics, University of Oxford, Oxford, UK. [online] URL: http://www.gprg.org/pubs/workingpapers/ pdfs/gprg-wps-003.pdf

Kiss, A., editor. 1990. Living with wildlife: wildlife resource management with local participation in Africa. World Bank, Washington, D.C., USA.

Klasen, S. 2000. Measuring poverty and deprivation in South Africa. Review of Income and Wealth 46:33-58. http://dx.doi. org/10.1111/j.1475-4991.2000.tb00390.x

Kolenikov, S., and G. Angeles. 2009. Socioeconomic status measurement with discrete proxy variables: is principal component analysis a reliable answer? Review of Income and Wealth 55:128-165. http://dx.doi.org/10.1111/j.1475-4991.2008.00309. $\underline{\mathrm{x}}$

Lechner, M. 2002. Some practical issues in the evaluation of heterogeneous labour market programmes by matching methods. Journal of the Royal Statistical Society. Series A 165:59-82. http://dx.doi.org/10.1111/1467-985X.0asp2
Leuven, E., and B. Sianesi. 2003. PSMATCH2: Stata module to perform full Mahalanobis and propensity score matching, common support graphing, and covariate imbalance testing. Version 3.1.5.

Levine, S. 2007. Trends in human development and human poverty in Namibia. United Nations Development Programme (UNDP), Windhoek, Namibia. http://dx.doi.org/10.2139/ $\underline{\text { ssrn.1031829 }}$

Lise, W. 2000. Factors influencing people's participation in forest management in India. Ecological Economics 34:379-392. http://dx.doi.org/10.1016/S0921-8009(00)00182-8

Long, S. A., editor. 2004. Livelihoods and CBNRM in Namibia. The findings of the WILD project. Wildlife Integration for Livelihood Diversification Project, Windhoek, Namibia.

Lubell, M. 2002. Environmental activism as collective action. Environment and Behavior 34:431-454. http://dx.doi. org $/ 10.1177 / 00116502034004002$

Matta, J. R., and J. R. R. Alavalapati. 2006. Perceptions of collective action and its success in community based natural resource management: an empirical analysis. Forest Policy and Economics 9:274-284. http://dx.doi.org/10.1016/j. forpol.2005.06.014

Mendelsohn, J., A. Jarvis, C. Roberts, and T. Robertson. 2002. Atlas of Namibia. David Phillip, Cape Town, South Africa.

Moser, C., and A. Felton. 2007. Intergenerational asset accumulation and poverty reduction in Guayaquil, Ecuador, 1978-2004. Pages 15-50 in C. Moser, editor. Reducing global poverty: the case for asset accumulation. Brookings Institution Press, Washington, D.C., USA.

Murphree, M. W. 1993. Communities as resource management institutions. International Institute for Environment and Development, London, UK. [online] URL: http://pubs.iied.org/pdfs/8284IIED.pdf

Murphree, M. W. 2004. Communal approaches to natural resource management in Africa: from whence and to where? Journal of International Wildlife Law and Policy 7:203-216. http://dx.doi.org/10.1080/13880290490883250

Namibian Association of Community Based Natural Resource Management (CBNRM) Support Organisations (NACSO). 2005. Namibia's communal conservancies. A review of progress and challenges in 2005. Namibian Association of Community Based Natural Resource Management (CBNRM) Support Organisations (NACSO), Windhoek, Namibia.

Namibian Association of Community Based Natural Resource Management (CBNRM) Support Organisations (NACSO). 2011. Namibia's communal conservancies. A review of progress-2010. Namibian Association of Community Based 
Natural Resource Management (CBNRM) Support Organisations (NACSO), Windhoek, Namibia.

Narayan, D., R. Patel, K. Schafft, A. Rademacher, and S. Koch-Schulte. 2000. Voices of the poor: can anyone hear us? Oxford University Press, New York, New York, USA.

Nelson, F., and A. Agrawal. 2008. Patronage or participation? Community-based natural resource management reform in sub-Saharan Africa. Development and Change 39:557-585. http://dx.doi.org/10.1111/j.1467-7660.2008.00496.x

Newmark, W. D., and J. L. Hough. 2000. Conserving wildlife in Africa: integrated conservation and development projects and beyond. BioScience 50:585-592. http://dx.doi. org/10.1641/0006-3568(2000)050[0585:CWIAIC ]2.0.CO;2

Norton, A., and M. Foster. 2001. The potential of using sustainable livelihoods approaches in poverty reduction strategy papers. Centre for Aid and Public Expenditure, Overseas Development Institute (ODI), London, UK. [online] URL: http://www.odi.org.uk/sites/odi.org.uk/files/odi-assets/ publications-opinion-files/2724.pdf

Paim, L. 1995. A consumption model for measuring poverty: an exploratory exercise. Social Indicators Research 35:129-153. http://dx.doi.org/10.1007/BF01079024

Petrovici, D. A., and M. Gorton. 2005. An evaluation of the importance of subsistence food production for assessments of poverty and policy targeting: evidence from Romania. Food Policy 30:205-223. http://dx.doi.org/10.1016/j.foodpol.2005.02.002

Pritchett, L. 2002. It pays to be ignorant: a simple political economy of rigorous program evaluation. Journal of Economic Policy Reform 5:251-269. http://dx.doi. org/10.1080/1384128032000096832

Qizilbash, M. 2003. Vague language and precise measurement: the case of poverty. Journal of Economic Methodology 10:41-58. http://dx.doi.org/10.1080/13501780$\underline{32000042059}$

Ravallion, M. 2003. Assessing the poverty impact of an assigned program. Pages 103-122 in F. Bourguignon and $\mathrm{L}$. Pereira da Silva, editors. The impact of economic policies on poverty and income distribution. Evaluation techniques and tools. World Bank, Washington, D.C., USA.

Ravallion, M. 2007. Evaluating anti-poverty programs. Pages 3787-3846 in T. Paul Schultz and J. A. Strauss, editors. Handbook of Development Economics. Elsevier, Amsterdam, The Netherlands. http://dx.doi.org/10.1016/S1573-4471(07) 04059-4

Roe, D., F. Nelson, and C. Sandbrook, editors. 2009. Community management of natural resources in Africa. Impacts, experiences and future directions. International Institute for Environment and Development, London, UK. [online] URL: http://pubs.iied.org/pdfs/17503IIED.pdf
Rosenbaum, P. R., and D. B. Rubin. 1983. The central role of the propensity score in observational studies for causal effects. Biometrika 70:41-55. http://dx.doi.org/10.1093/biomet/70.1.41

Sahn, D. E., and D. C. Stifel. 2000. Poverty comparisons over time and across countries in Africa. World Development 28:2123-2155. http://dx.doi.org/10.1016/S0305-750X(00)00075-9

Sahn, D. E., and D. C. Stifel. 2003. Exploring alternative measures of welfare in the absence of expenditure data. Review of Income and Wealth 49:463-489. http://dx.doi.org/10.1111/ j.0034-6586.2003.00100.x

Sanderson, S. 2002. The future of conservation. Foreign Affairs 81:162-173. http://dx.doi.org/10.2307/20033275

Shadish, W. R., T. D. Cook, and D. T. Campbell. 2002. Experimental and quasi-experimental designs for generalized causal inference. Houghton Miflin, Boston, Massachusetts, USA.

Suich, H. 2010a. The livelihood impacts of the Namibian community based natural resource management programme: a meta-synthesis. Environmental Conservation 37(1):45-53. http://dx.doi.org/10.1017/S0376892910000202

Suich, H. 2010b. The elephant in the room. The impacts on poverty of wildlife-focussed community based natural resource management. The Tchuma Tchato Project, Mozambique and Kwandu Conservancy, Namibia. Dissertation. Australian National University, Canberra, Australia.

Suich, H. 2013. The effectiveness of economic incentives for sustaining community based natural resource management. Land Use Policy 31:441-449. http://dx.doi.org/10.1016/j. landusepol.2012.08.008

Suich, H., B. Child, and A. Spenceley, editors. 2009. Evolution and innovation in wildlife conservation: parks and game ranches to transfrontier conservation areas. Earthscan, London, UK.

Tagg, J. 1996. Caprivi. Namibia's best kept secret. Pages 66-69 in P. Tarr, editor. Namibia environment. Volume I. Ministry of Environment and Tourism, Foreign and Commonwealth Office (UK), British Council, Namibia Nature Foundation, Windhoek, Namibia.

Taylor, R. D. 2009. The performance of CAMPFIRE in Zimbabwe: 1989-2006. Pages 201-222 in H. Suich, B. Child, and A. Spenceley, editors. Evolution and innovation in wildlife conservation: parks and game ranches to transfrontier conservation areas. Earthscan, London, UK.

United Nations Development Programme (UNDP). 2000. Mozambique: national human development report, 2000. Education and human development: trajectory, lessons and challenges for the 21st century. United Nations Development Programme Mozambique, Maputo, Mozambique. 
United Nations Development Programme (UNDP). 2006. Mozambique: country brief. United Nations Development Programme Mozambique, Maputo, Mozambique.

United Nations Economic Commission for Africa (UNECA). 2008. Securing our future. Report of the Commission on HIV/ AIDS and Governance in Africa. United Nations Economic Commission for Africa, Addis Ababa, Ethiopia. [online] URL: http://reliefweb.int/sites/reliefweb.int/files/resources/ B1DFA7449D85002D85257494006F4846-UNCTAD Jun08. pdf

Walpole, M., and L. Wilder. 2008. Disentangling the links between conservation and poverty reduction in practice. Oryx 42:539-547. http://dx.doi.org/10.1017/S0030605308000744

Western, D., R. M. Wright, and S. C. Strum, editors. 1994. Natural connections: perspectives in community-based conservation. Island, Washington, D.C., USA. 